Каролина Лендак-Кабок

(Lendák-Kabók Karolina) ${ }^{1}$

Филозофски факултет,

Универзитет у Новом Саду, Нови Сад
Оригинални научни рад

UDK 392.5:323.111(497.113)

Примљено: 02.11.2020.

Ревидирана верзија: 25.11.2020.

Одобрено за штампу: 26.11.2020.

DOI: https://doi.org/10.46630/gsoc.26.2021.03

\title{
ДЕЦА ДЕВЕДЕСЕТИХ У ВОЈВОДИНИ: МЕШОВИТИ БРАКОВИ И ЕТНИЧКИ ИДЕНТИТЕТ ${ }^{2}$
}

\begin{abstract}
Anстракт: Иако Војводина током ратова деведесетих година није била поприште ратних сукоба, последице рата још увек су присутне. Неки сматрају да је Покрајина коју одликује мултиетничко становништво избегла ескалацију ратних догађања делимично због релативно високе стопе мешовитих бракова. Иако су ратови били трауматични за све у Војводини, они су можда најтеже погодили миленијалце припаднике националних мањина, који су се тако суочили са отвореним национализмом, отуђењем и осећајем другости. За миленијалце рођене у мешовитим браковима, једна од прекретница у животу био је избор језика наставе (већинског или мањинског) на почетку школовања. Циљ рада је да истражи образовни елемент у вишестраном оквиру који утиче на одлуке родитеља и последице које су те одлуке имале на миленијалце и изградњу њиховог идентитета. Анализа се заснивала на полуструктурираним интервјуима вођеним са миленијалцима који су рођени у (српско-мађарским) мешовитим браковима. Резултати показују да је одабир језика школовања био претежно родно заснован, односно да су очеви одлучивали о томе да су се испитаници/це ${ }^{3}$ који су уписали/е основну школу на српском језику одвојили од мањинског идентитета, те чак и у случају да су очували језик националне мањине, он је постао само средство за даље напредовање у каријери, а не веза са њиховом мањинском заједницом. Испитаници који су основну школу уписали на мањинском језику очували су чвршћу везу са мањинском заједницом и изградили идентитет припадника националне мањине. Обе групе су се током школовања суочавале са непријатним ситуацијама подстакнутим национализмом, што је неизбежно утицало на изградњу њиховог идентитета.
\end{abstract}

Кључне речи: мештовити бракови, образовање, језик, национална припадност, идентитет, деведесете године, миленијалци, Војводина

\footnotetext{
${ }^{1}$ karolina.lendak@uns.ac.rs

${ }^{2}$ Истраживање је спроведено у оквиру програма „Право на прву шансу“ Покрајинског секретаријата за високо образовање и научноистраживачку делатност Аутономне покрајине Војводине.

${ }^{3}$ У даљем тексту испитаници.
} 


\section{Увод}

Миленијалци у постсоцијалистичким земљама у Европи су у посебно рањивом, чак и несигурном, положају, будући да је прелазак из социјализма у неолиберализам оживео класне, полне и етничке социјалне разлике (Ule, 2012: 40). Миленијалци рођени у Аутономној Покрајини Војводини ${ }^{4}$ (у даљем тексту: Војводина), били су деца током деведесетих година, периода прожетог етничким сукобима и рађањем мржње и непријатељства према националним мањинама, одн. према свима који су се разликовали (Савић 2006). Последице националистичких ставова у Србији и даље се осећају (Нађ 2006) и доводе до високе стопе исељења припадника националних мањина (Márton 2014). Сукоби подстакнути ратом јачају осећај инфериорности код припадника националних мањина (Szerbhorváth 2018), који се заснива на припадности другој нацији, упркос њиховој (законској) равноправности са већином, одн. могућности да користе свој (књижевни) језик у школи, постојању медија на матерњем језику и могућности коришћења свог језика у јавном животу (Maran 2013). Припадници националне мањине имају често осећај да се држава у којој живе устројава и води у корист већине, што може угрожавати њихов идентитет (Kyriazi 2018). Како би неутралисали те последице, они се или окрећу матичним државама (Kyriazi 2018) или покушавају да се 'приближе' већинском народу у својој држави (Kemp 2006). Један од могућих начина да се другопоменуто постигне јесте кроз склапање мешовитог брака, односно бирањем супружника из већинске нације (Ноóz 2002). Ботев сматра да је одржавање мира у Војводини током ратова у Југославији деведесетих година делимично и заслуга великог броја мешовитих бракова (Botev 1994: 467).

Друштвене карактеристике, попут образовања, занимања, расе и етничке припадности, јесу ресурси које супружници доносе у брак и сматрају се „културним значкама“" које појединци носе како би показали своје квалитете (Kalmijn 1998: 400). Појединци рођени у мешовитом браку, стога, имају више културних ресурса и могу имати више од једног етничког идентитета (Song 2009), али врло често морају да се определе за једно етничко обележје (Kiss 2018: 483). На тај начин афирмишу један од својих идентитета на штету оног другог. Њихова припадност одређеном идентитету може ојачати или ослабити тако што њихови родитељи бирају наставни језик њиховог школовања. Када родитељи одаберу језик већине као наставни, они покушавају да се приближе већинској нацији јер је добро познавање језика већине значајно уколико њихова деца желе да „постоје“, напредују и граде каријеру у земљи у којој су рођена (Papp 2017: 97).

Изградња идентитета деце из мешовитих бракова је питање које има и родну димензију, јер се од мајки очекује да одржавају традиционалне појмо-

\footnotetext{
${ }^{4}$ Војводина није аутономна територија по националној основи, већ је вишенационална регија са 25 различитих етничких група, међу којима је мађарска национална мањина највећа и чини 13\% становништва Војводине (Завод за статистику Републике Србије, 2012).
} 
ве женских улога (Thomson 2020), те су оне задужене за праћење и подршку током школовања своје деце. Раније студије о етничким мешовитим браковима у Војводини заснивале су се на јавно доступним статистичким анализама података (Botev 1994), а врло мало значаја придавано је појединцима рођеним у етничким мешовитим браковима на основу квалитативног истраживања (Özateşler-Ülkücan 2019). Овај рад посвећује посебну пажњу миленијалцима који су одрастали деведесетих и који су рођени у (српско-мађарским) мешовитим браковима.

Циљ рада је да на квалитативним подацима илуструје полазну правилност у погледу повезаности истраживаних појава (језик образовања-дистинкција/ акултурација националних мањина - ратна догађања и национализам) у датом контексту (Војводина) на изабраним примерима (деца из мешовитих бракова рођена током 1980-их), као и да укаже на утицај појединих чинилаца.

\section{Мешовити бракови}

Мешовити бракови служе као главни показатељ акултурације или чак асимилације (Merton 1972; Blau и група аутора 1984; Labov \& Jacobs 1986; Pagnini \& Morgan 1990; Sokolovska 2008) и, пошто доводе у питање концепт подељености, мешовити бракови су још увек контроверзни (Osanami Törngren 2016). Будући да се брак сматра механизмом за пренос етнички специфичних културних вредности и пракси на следећу генерацију, мешовити бракови могу суштински утицати на границе и дистинкцију националних мањинских заједница (Barth 1969), као и на природу интеркултурне комуникације (Лазар и Аћимов 2017). У литератури о томе „ко се с ким венчава“ доминирају две теме: (1) брак као размена друштвених, економских и личних односа између супружника и (2) брак као показатељ асимилације или друштвене дистанце (Schoen, Wooldredge \& Thomas 1989: 617). На мешовите бракове се дуго гледало као на одраз односа између група и јачине граница између група (Groden 1964). Велики број мешовитих бракова између мањинске и већинске групе истовремено указују на прихватљивост већинске заједнице према мањинској, као на неизбежно слабљење дистинкције и карактеристика мањинске групе (Schoen, Wooldredge \& Thomas 1989: 618). Ако прихватимо да мешовити бракови показују истинско друштвено прихватање 'других' као једнаких, онда такође можемо да закључимо да нам они деконструишу етничке и расне предрасуде према одређеним мањинским групама у друштву (Song 2009: 333). Из тих разлога, мешовити бракови се обично сматрају показатељем успеха и друштвеног прихватања мањинске групе (Song 2009).

Међутим, схватање мешовитог брака као чудотворног лека за постизање друштвене хармоније и кохезије јесте ипак донекле наивно (Rodríguez-García и група аутора 2016: 2). Једном када се склопе мешовити бракови између припадника различитих група, улогу ће почети да игра још један аспект мешовитог брака: његова функција повезујућег елемента у друштву јер мешовити бракови 
не повезују само две особе, већ и веће групе којима те особе припадају (Smiths 2010: 421). Није реч само о двоје људи (пару), већ о породици са свим члановима који међусобно ступају у најличнији однос (Нoóz 2002: 1090). Мешовити бракови такође могу да постану поприште за конфликте унутар породица (Rodríguez-García и група аутора 2016), стога породица представља важан контекст за друштвену интеракцију и узајамно прихватање између етничких група у друштву (Huijnk 2011: 15).

Ботев (1994) сматра да су мешовити бракови у бившој Југославији били под утицајем културне традиције различитих народа и држава у којима су раније живели, што је умногоме утицало на одабир супружника. Тако је, на пример, мађарска национална мањина имала најмање „препрека“ за склапање етнички мешовитих бракова у Војводини, односно, била је најотворенија према етничко мешовитим браковима са другим етнички различитим припадницима југословенског друштва, јер су Мађари у Аустро-Угарској монархији били отворенији за склапање бракова према етничким групама које су постале конститутивни народи у Југославији (Botev 1994).

\section{Идентитет, национална припадност и род током ратова у Југославији}

Веза са одређеном територијом или нацијом је одувек била важан фактор припадности и саставни део идентитета (Örkény 2005: 46). Међугрупне друштвене категорије и границе могу се превазићи стварањем хибридних и трансформативних идентитета (Özateşler-Ülkücan 2019: 2). Када је реч Војводини, становници Војводине имају регионални, војвођански идентитет као колективни, али и вишеструке идентитете који не постоје нужно у хијерархији, већ им се заправо даје приоритет у зависности од контекста (Шарачевић 2012: 3). Вишеструки идентитети се могу развити баш због тога што етничке заједнице у Војводини имају различите групне социодемографске карактеристике (Илић и Цвејић 1997). Војвођански мађарски идентитет се развио и изградио у доба

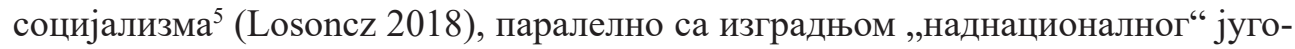
словенског идентитета, идентитетског обрасца који је „отелотворење“ принципа „братства и јединства“ (Godina 1998: 416), али је био донекле ослобођен етничких и класних разлика (Tóth 2019). Од тог времена, војвођански мађарски национални идентитет може се разликовати од шире (или можда првобитне?) мађарске нације (Bálint 2012: 454), чији идентитет је историјски, друштвено и политички одређен и релативно брзо се мења (Чудић 2017). Данас се даје предност националној идентификацији; сходно томе, онима који „оклевају“ или су „на корак да постану припадници већинске нације“ може бити ускраћено признавање статуса етничке мањине (Öllős 2012). Такво, наизглед ирационално,

\footnotetext{
${ }^{5}$ Пре 1920. године је ова регија била у склопу Аустроугарског царства, тако да Мађари који су живели у на територији данашње Војводине нису имали засебан, регионални идентитет.
} 
понашање доводи до смањења националних заједница, уместо да се оне развијају прихватањем оних који су у етнички мешовитој ситуацији (Kiss 2018: 491), одн. оних који потичу из мешовитих бракова.

Генц (2004) у свом истраживању са почетка двехиљадитих година наводи да су они који су имали мешовите националне идентитете имали проблем са свешћу о националној припадности, јер је припадност националној мањинској заједници постала терет и у неку руку и непријатност у деведесетим годинама прошлог века (Göncz 2004). У том смислу, акултурација је постала важан концепт у објашњењу разноврсних искустава националних и културних мањина (Trimble 2003: 5), укључујући губитак мањинског идентитета или делова тог идентитета, (губитак матерњег језика, промена друштвених мрежа или мењање културних вредности) (Phinnei 2003).

Одржавање и постојање националних заједница у држави има и родну димензију. Наиме, жене симболички репродукују своје етничке и националне колективе (Kandiyoti 1994), као и радну снагу, своје породице и грађанство својих држава, кроз пројекцију културних вредности и колективне тежње (Thomson 2020: 10), те се на њих гледа и као на „мајке нације“ (Bracewell 1996). Прис (Preece 2008: 57) наводи да се употреба и очување наслеђа језика очекује од жена, припадница националних мањина (Yuval-Davis 1997: 196). У патријархалној породичној јединици на чијем је челу мушкарац, улога жене одражава традиционалне појмове женских улога (Thomson 2020), што подразумева и бригу о идентитетском развитку деце у породици. У турбулентном временском периоду, као што су ратна догађања, женски гласови губе сву преговарачку моћ (Thomson 2020) што може резултирати маргинализацијом значаја очувања мањинског идентитета у породици. С тим у вези Рац наводи да је током ратова на територији бивше СФРЈ, у духу „афирмативног есенцијализма“ (Fox 1996) улога жена традиционално сведена на одржавање моралне чистоте, миротворства и бриге о друштву (Rácz 2018: 12).

\section{Избор наставног језика у школи}

Када је реч о очувању мањинских група унутар држава, образовање на матерњем језику је пресудно за очување националног идентитета. Образовање одржава културни и језички облик државе (Мау 2012: 132), а „интеграција у јединствену језичку заједницу је императив“ за скоро сваку државу (Bourdieu 1991: 46). Стога, етничке мањине у државама у којима живе теже ка формалној институционализацији образовања на матерњем језику и користе свој језик у школи као средство за спречавање или смањење асимилације (Раpp 2014). Родитељи у неким државама у региону, као што су Словачка или Украјина сматрају да образовање на мањинском језику не пружа довољно могућности, па се одлучују за школовање на већинском језику које ће развити компетенције деце на службеном (већинском) језику што је важно ако желе да „постоје“, напредују и граде каријеру код куће (Рарр 2017: 97). Настава на мањинским језицима 
сноси ризик за ученике етничких мањина у Србији, јер завршетак основног и средњег образовања на мањинском језику, са свега неколико сати недељно српског као језика средине, створило би генерације неуравнотежених двојезичних говорника, које карактерише врло ниски ниво знања српског језика (Филиповић и други аутори 2007) који често говоре са акцентом (Russo и други аутори, 2017). У преласку са средњошколског образовања на универзитетско образовање на већинском језику, студенти из националних мањина у таквој ситуацији прво треба да превазиђу језичку баријеру, односно да на почетку студија науче српски језик, што захтева време, труд и одрицање (Lendák-Kabók \& Lendák 2017).

\section{Методологија}

Овај рад 6 се заснива на квалитативним подацима, одн. осам полуструктурираних интервјуа (седам жена и један мушкарац) обављених са миленијалцима који су рођени у мешовитим (српско-мађарским) браковима.

Приликом избора испитаника кориштен је метод грудве снега (Esterberg 2011). Интервјуи су вођени између септембра и децембра 2019. године на мађарском и српском језику. Одломке интервјуа који су изворно били на мађарском, ауторка је превела на српски језик. Испитаници су рођени између 1981. и 1989. године и одрасли су у различитим деловима Војводине, и то у Ади, Ченеју, Малом Иђошу, Молу и Новом Саду. Разлика између општина у којима су рођени и одрасли саговорници из мањинских заједница значајна је за разумевање става испитаника према националној припадности и језику. Поменуте општине се разликују по етничком саставу. У Новом Саду и Ченеју већина становништва су Срби, па су испитаници већински језик савладали на вишем нивоу, због веће интеракције са већинским становништвом, док су у Ади, Малом Иђошу и Молу Мађари у већини, стога је етнички састав тих општина обично утицао на то да испитаници мање користе језик већине, односно државни језик.

Идентитет испитаника анонимизиран је употребом кодова уместо имена. За кодове су кориштени иницијали њихове националне припадности на енглеском језику, затим иницијали за њихов пол, а број на крају показује њихову старост (што је број већи, то је особа млађа), на пример, ИФ1 (енг.: intermarriage female - жена из мешовитог брака) рођена 1981. године, или ИМ1 (енг.: intermarriage male - мушкарац из мешовитог брака) рођен 1984. године.

Упитник за интервју се састојао од двадесет питања која су се надовезивала једно на друго и била су подељена у три главне теме, наиме (1) детињство, школовање и последице периода деведесетих у Војводини; (2) војвођански

\footnotetext{
${ }^{6}$ Рад је део већег истраживања који се састоји од двадесет шест (26) интервјуа (двадесет један са женским и пет са мушким испитаницима), вођених са миленијалцима који су из мањинских етнички хомогамних бракова или мешовитих бракова. Богата и разнолика позадина испитаника знатно отежава могућност да се сви интерјуви анализирају у једном научном раду, те сам се одлучила да у овом раду прикажем само део истражвања.
} 
идентитет; (3) културне разлике у породици. У раду ће бити анализирана питања везана за језик школовања, породични разлози за избор школовања на језику мањине или већине, са посебним фокусом на бурни период деведесетих година у бившој Југославији, односно Војводини.

Приликом анализе квалитативних података кориштени су методи кодирања које су осмислили Салдана (Saldana 2013) и Маквин и група аутора (MacQueen 2009). Као прво, примењено је атрибутско кодирање (Saldana 2013: 70) како би се добио увид породични статус, као и рано детињство, школовање и окружење испитаника у време интервјуа (резултати су приказани у Табели 1 у додатку).

За анализу интервјуа примењена је наративна анализа (Law 2004), jep се наративно истраживање бави начинима на које појединци и групе тумаче друштвени свет и своје место у њему (Law 2004). Због тога су у средишту анализе значења која људи приписују догађајима о којима говоре у својим наративима (Aavik 2015).

\section{Резултати}

Резултати ће представити језик школовања, разлоге из којих се бира школовање на језику мањине или већине и њихов утицај на миленијалце рођене у мешовитим браковима. Одељак са резултатима је подељен на два дела. У првом делу ће се анализирати наративи испитаника који су своје образовање завршили на језику већине, са посебним нагласком на евентуалне инциденте повезане са коришћењем мањинског језика у јавном простору или националном припадношћу, током бурног периода деведесетих година. У другом делу биће представљена анализа утицаја школовања на језику мањине, као и утицај ратова у Југославији на коришћење мањинског језика или етничку припадност.

Као што се може видети из Табеле 1 са атрибутским кодовима, две испитанице (ИФ1 и ИФ5) ишле су у мађарску основну и средњу школу, две испитанице су похађале (ИФ3 и ИФ7) основну школу на мађарском, а средњу школу на српском, док је четворо испитаника (ИФ2, ИФ4, ИФ6, и ИМ1) похађало већинску (српску) основну и средњу школу. Њихово породично окружење биће кратко представљено приликом анализе њихових наратива. 
Табела 1: атрибутски кодови за испитанике

\begin{tabular}{|c|c|c|c|c|c|c|c|c|c|c|}
\hline$\stackrel{\mathfrak{x}}{\mathfrak{0}}$ & 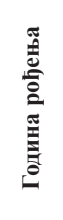 & 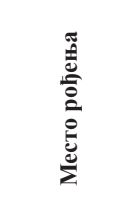 & $\sum^{\frac{N}{z}}$ & 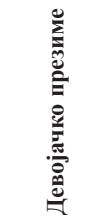 & 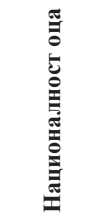 & 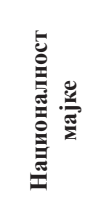 & 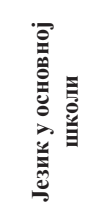 & 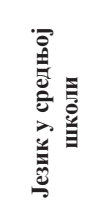 & 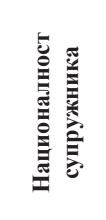 & 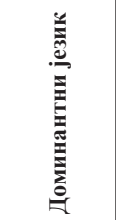 \\
\hline ИФ2 & 1981 & Мали Иђош & српско & српско & српска & мађарска & мађарски & мађарски & - & мађарски \\
\hline ИФ2 & 1982 & Нови Сад & $\begin{array}{c}\text { српско / } \\
\text { мађарско }\end{array}$ & мађарско & мађарска & српска & српски & српски & српска & српски \\
\hline ИФ3 & 1983 & Ченеј & српско & српско & српска & мађарска & мађарски & српски & српска & српски \\
\hline ИФ4 & 1984 & Нови Сад & српско & српско & српска & $\begin{array}{c}\text { мађарска } \\
\text { и } \\
\text { хрватска }\end{array}$ & српски & српски & српска & српски \\
\hline ИФ5 & 1986 & Нови Сад & српско & српско & српска & мађарска & мађарски & мађарски & мађарска & $\begin{array}{l}\text { српски и } \\
\text { мађарски }\end{array}$ \\
\hline ИФ6 & 1986 & Ада & српско & $\begin{array}{l}\text { мађарско } \\
\text { и српско }\end{array}$ & мађарска & српска & српски & српски & српска & српски \\
\hline ИФ7 & 1989 & Нови Сад & $\begin{array}{l}\text { српско и } \\
\text { мађарско }\end{array}$ & мађарско & мађарска & српска & мађарски & српски & српска & српски \\
\hline ИМ1 & 1984 & Мол & српско & - & српска & мађарска & српски & српски & мађарска & српски \\
\hline
\end{tabular}

\section{Утицај школовања на већинском језику и деведесете године}

Већина испитаника који су основну и средњу школу завршили на српском језику, нису се сетили ниједног конкретног разговора по том питању у оквиру породице, већ им је то што су се школовали на српском језику деловало природно. Неки од испитаника су током интервјуа говорили на српском језику, што указује на висок ниво акултурације, као и на губитак мањинског језика (Ноóz 
2002), што не зависи само од појединца већ и од националног састава општине у којој су одрасли и у којој живе. Они који су одрасли и још увек живе у општинама у којима се мађарски језик користи и у јавној сфери у већини ситуација немају потешкоћа (или су оне сведене на минимум) да говоре на мађарском језику, док они који су у већинском српском окружењу, као што је то Нови Сад, имају мање шансе за очување мањинског језика

ИМ1 је током интервјуа разговарао на мађарском. Његов отац је Србин, а мајка Мађарица, али му је и бака по оцу била Мађарица. Он има српско име, а његова сестра и он су се школовали на српском језику у већинском мађарском окружењу, у Молу и Сенти. Изјавио је да се не сећа договора његових родитеља да он похађа школу на српском језику и никада касније није доводио у питање ту њихову одлуку. Могло би се рећи да је (делимична) припадност његовог оца већинској нацији била „културна значка“ коју су његови родитељи прихватили кроз његово образовање (Kalmijn 1998). Испитаник се дружио са припадницима обе етничке заједнице, без обзира на то што је ишао у српску школу. Он са̂м говори о томе у интервјуу да му је српски језик јачи, те му је то и први језик, али његов посао захтева да користи и мађарски и српски, те је његово знање мањинског језика служило као предност при проналажењу посла. Одломак из његовог интервјуа следи:

[Моје школовање на српском језику] је било због мог оца, али он се не изјашњава као Србин; и њему је мајка Мађарица, али некако се тако десило. Не знам да ли сумоји родитељи разговарали о томе, али то је за юих било природно. Ишао сам у вртић на мађарском и већ тада сам развио двојезичност; од тада сам двојезичан, српски ми је мало јачи, али и мађарски језик ми је сасвим добар. Такође радим на мађарском. (ИМ1)

Инциденти изазвани због употребе мањинских језика могли су се догодити током деведесетих година, када су испитаници били још деца или су ишли у основну школу. То није увек било повезано само са њиховом употребом мањинског језика, већ и са њиховом националном идентификацијом и то конкретно именом. Углавном се присећају да су у школи доживели „задиркивање“" од стране других ученика, али било је и других „инцидената“.

ИМ1 у свом наративу истиче да је увек био негде „између“; с обзиром на то да је ишао у српски разред, али је имао много пријатеља Мађара. Када су се ти „окршаји банди“ на националној основи одигравали у основној школи, морао је да пронађе равнотежу, јер су га због школовања на српском језику сматрали за неког ко је „на корак да постане припадник већинске нације“ (Öllős 2012). У свом наративу истиче да туче засноване на националној припадности нису представљале значајније сукобе. Када је био студент у Новом Саду, почетком двехиљадитих, био је у ситуацији да су други прокоментарисали његову употребу мањинског језика, што описује на следећи начин:

Током деведесетих је било свађа банди на националној основи, које су завршавале тучом, али није било случајева организованог обрачуна или претеране мржюе. Знам да је било таквих ситуащија у Новом Саду деведесетих, али док сам 
тамо студирао, почео сам 2003. године и био сам у Новом Саду до 2008/9, то се никада није догодило ..., мада се једном десило када сам био у већем друштву и ушли смо у неку пекару или ресторан брзе хране и тамо је неко прокоментарисао о томе у позадини, па сам отишао до њега и рекао му како ствари стоје, тако да је то једини случај из мог личног искуства. (ИМ1)

Иако ИМ1 у свом исказу не објашњава шта је тачно урадио када је разрешио инцидент везан за употребу мањинског језика, чињеница да је Војводина била и да је још увек вишејезична и мултикултурна средина налаже да се људи позивају на међусобну толеранцију при националистичким коментарима.

ИФ2 је током интервјуа говорила на српском језику. Мајка јој је била Српкиња, а отац Мађар7, код куће су користили оба језика - с оцем је разговарала на мађарском, а комуникација са мајком и сестром била је углавном на српском, тако да је у њеној породици била чешћа употреба већинског језика. Ишла је у школу на српском језику у већинском српском окружењу у Новом Саду. Девојачко име и презиме јој је било мађарско. Њена школа је имала и мађарска одељења ${ }^{8}$, али су њени родитељи одлучили да њу и сестру упишу у српско одељење. Ово је и њој било сасвим природно, као и код ИМ1 никада није преиспитивала одлуку својих родитеља или размишљала о истој. Могуће да је то било више због њене сестре, пошто су се често селили по граду док су њих две биле мале, а прва школа у коју су њени родитељи уписали сестру била је близу њихове куће, али није имала наставу на мађарском. После су обе уписали у школу која је имала мађарско одељење, али њихови родитељи нису променили језик наставе, тако да су обе ишле у српско одељење. Иако је нагласила да јој је сестра имала пријатеље из мађарског одељења, са којима је и даље у контакту, ИФ2 није рекла да ли је имала исто искуство.

Јесам [иколовање сам завршила на српском], као и моја сестра. Она се тада дружила, а дан-данас се дружи са пријатељима из мађарског одељења Петефи

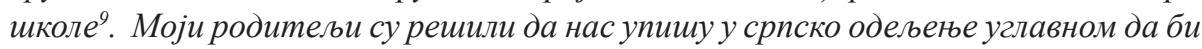
нам касније било лакше, а ми смо се неколико пута селили јер су моји родитељи y почетку били подстанари... па мислим да им је тако било лакше јер је моја сестра променила две школе, ... пре него што сам ја кренула у ту школу коју је завршила. (ИФ2)

Испитаници ИФ2 је српски језик доминантан, она није ни користила мађарски у периоду од десет година што је испричала у наставку интервјуа. То се променило када је родила своје прво дете и одлучила да га упозна са мањин-

\footnotetext{
${ }^{7}$ Обоје су преминули.

${ }^{8}$ Тренутно у Новом Саду постоји настава на мађарском језику у три основне и четири средње школе. Раније, када се више ученика првог разреда уписивало у мађарско одељење, више основних школа имало је једно мађарско одељење по разреду.

${ }^{9}$ Основна школа Петефи Шандор је позната и угледна школа у Новом Саду. Име је добила по чувеном мађарском песнику, који је написао песму Nemzeti dal („Песма нације“) за коју се наводи да је подстакла Мађарску револуцију 1848. године. У револуцији је погинуо као херој. Школа је позната и по томе што има једно одељење на мађарском по разреду.
} 
ским језиком, разговарајући с њим на мађарском. На то гледа као на инвестицију у њихову будућност јер им језичка компетенција може обезбедити додатне могућности. Међутим, за њу је додатно напорно да говори на мађарском јер су њене језичке способности ослабиле. Испитаница у свом интервјуу истиче да није доживела било какве непријатности због свог мешовитог идентитета, али је истакла важност да се српски језик говори беспрекорно и без икаквог нагласка што је по њеном мишљењу највећи недостатак хомогамне породице мађарске националне мањине (Russo и група аутора 2017) који по њеном мишљењу произилази из недовољног улагања труда да се усаврше вештине већинског језика. Из ове изјаве се могло закључити да је у њеној идентитетској конструкцији српски језик важнији од мађарског.

Како су жене те које преносе културу и које су привилеговани означитељи националне разлике (Kandiyoti 1994: 377), оне у мешовитим браковима тумаче ту улогу при културној репродукцији сопственог идентитета кроз школовање. То је био случај са ИФ6, чији је отац Мађар, а мајка Српкиња. Она се школовала на српском језику, у претежно мађарском окружењу, Ади. Њено девојачко презиме било је мешавина српске и мађарске припадности, наиме, прво од два презимена било је мађарско, а друго српско. Одлуку о школовању на српском језику, родитељи су повезали са слободним временом њене мајке, јер је она била више код куће и помагала им са школским задацима. Током интервјуа је говорила на српском, причала је о важности усавршавања српског језика, као што је то био случај и са ИФ2. То је за њу важно, јер живи у Србији и не осећа ништа према Мађарској, како је нагласила у свом наративу. ИФ6? није научила да чита и пише на мађарском језику, због чега јој је сада жао и у наставку интервјуа је нагласила да ће, уколико буде постала мајка једног дана, покушати да пренесе мањински језик на своје дете, али да ће за то требати одобрење њеног супруга, који је из већинске заједнице. Следи одломак из њеног интервјуа:

Једна од юихових замисли је била, како је моја мајка више код куће, она може више да учи са нама, а друга, како живимо у Србији, сматрали су да је веома важно да знамо да правилно говоримо српски да не бисмо могли имати проблема касније. Увек сам их питала зашто су ме послали у српско одељење, јер сам мислила да бих могла да научим да правилно читам и пишем да идем у мађарско одељење... онда би ми одговорили, па зато што је мама више код куће и може да учи са нама и, верујте ми, након тога их више нисам питала за то и не знам да ли је постојао неки други разлог... (ИФб)

ИФ6 није доживела никакву дискриминацију због свог мешовитог порекла у Ади, где већинско становништво чине Мађари, потврђујући мирни заједнички живот етничких мањина у Војводини, као што наводе Илић и Цвејић (1997) у истраживању урађеном пре двадесет година. Следи одломак из интервјуа ИФ6:

Никада тамо нисам имала проблема јер сам пола Српкиња, пола Мађарица, јер су људи који тамо живе навикли на оба и никада није било проблема, ниједном током живота нисам осетила икакву дискриминащију због тога што сам пола 
Мађарица. Веома сам поносна на своје порекло уопште, и српско и мађарско, па кад се представим некоме, увек кажем да сам оба. (ИФб)

Мирни заједнички живот етничких мањина у Војводини је био једна од одлика војвођанског становништва, што наводе Илић и Цвејић (1997) у истраживању урађеном пре двадесет година.

\section{Утицај школовања на мањинском језику}

Школовање на мањинским језицима на основном нивоу образовања обично је био избор родитеља који је припадао мањинској заједници или родитеља из већинске заједнице, који је био врло свестан губитка мањинског језика у школском систему и окружењу већине. Иако су неки од испитаника основно образовање завршили на мађарском, због средњег образовања на српском и околине у којој су одрасли и живели, губитак њихових компетенција на мањинском језику је толики (Hoóz, 2002) да избегавају да га говоре јавно, већ више воле да говоре само на српском.

Неки од испитаника се сећају да су доживели дискриминацију у школи, на улици или у аутобусу, због своје националне припадности. То је било прилично често током деведесетих, када је национална припадност постала напета тема (Савић, 2006). ИФ1, чији је отац Србин, а мајка Мађарица, цео живот је провела са мајком у Малом Иђошу, а отац је живео на југу Србије. Има српско име, али је своје основно и средње образовање завршила на мађарском језику. Било је периода током деведесетих када јој је српско име или помогло или, пак, одмогло. У интервјуу је причала о инциденту када су њене пријатеље из разреда малтретирала деца из суседног села и нису их пустили из аутобуса због њихове националне припадности. Због свог српског имена, није доживела никакво насиље. Одломак њеног наратива следи:

Моје српско име ми је једном помогло, када смо се аутобусом враћали кући из средюе школе, јер Ловћенач ${ }^{10}$ и Мали Иђош били су у великој свађи. Касних деведесетих долазили су са ланциима у Мали Иђош из Ловћенца и биле су велике туче, није то дуго потрајало, али су многу деиу претукли и ищутирали, али то је био само период од неколико месеци. После тога је било мирно. У то време се не бисмо усудили да прођемо кроз Ловћенач или смо кроз Ловћенац пролазили са великим страхом. Сада влада потпуни мир. У Ловћениу, Црногоризи нису пуштали девојке из аутобуса у Малом Иђошу, хватали су их и чупали. Нису ме повредили јер су погледали свачије име у показној карти и мислили су да сам , юихова“". Била је и лоша страна тога што сам имала српско име, једном нисам добила мађарску стипендију од Костолањија ${ }^{11}$, иако сам цело школовање завршила на мађарском. (ИФ1)

\footnotetext{
10 Ловћенац и Мали Иђош су суседна села, у првом су насељени Црногорци, а друго је мађарско село на северу Бачке.

${ }^{11}$ Гимназија за талентоване ученике „Деже Костолањи“; у Суботици има наставу искључиво на мађарском језику, а финансијску подршку добија и од Мађарске. Наиме, њихови ученици имају могућност стипендирања.
} 
ИФ7, рођена и одрасла у Новом Саду, током интервјуа је говорила на мађарском, међутим, била је у некој мери суздржана и говорила је краћим реченицама, јер како је навела не користи често мађарски језик. Покојни отац јој је био Мађар, а мајка Српкиња, девојачко презиме и име јој је мађарско. Ишла је у вртић и основну школу на мађарском, али је завршила престижну гимназију у Новом Саду на српском језику. У свом исказу је имала мање позитивног става према школовању на мањинском језику јер је њен разред у основној школи био мали, са мање од десет ученика. Разлог опадања броја ученика у мађарским разредима је био рат у Југославији, јер када је ИФ7 кренула у основну школу 1995. године, из Србије је отишао велики број припадника мађарске националне мањине (Márton 2014). У свом одељењу се осећала непријатно због тога што је рођена у мешовитом браку а то је касније осетила и у српском окружењу, конкретно у поменутој елитној гимназији, због свог мешовитог порекла. ИФ7 је похађала часове мађарског језика у другој гимназији која је имала мађарско одељење. То је била жеља њеног оца и он је инсистирао на томе, те је положила све четири године из предмета Мађарски језик и књижевност и положила и матуру из мађарског језика. Треба напоменути да је њен отац био универзитетски професор, који је желео да сачува и мањински идентитет код своје деце и био је свестан да то може да се уради кроз образовање. Након што је њен отац преминуо, све мање користи мађарски језик. Део наратива ИФ7 следи:

Иила сам у вртић и основну школу на мађарском, али сам завршила гимназију на српском, и паралелно сам ишла и на часове мађарског у другој школи. На крају сваке године полагала сам испит из мађарског, имала сам разредни испит. Због тога имам ниво мађарског из средюе школе. У основној иколи сам доживела шовинизам од стране неколико наставника и юихово понашање је створило разлику између , чистих“ мађарских ученика и ученика из мешовите породице. А у средњој школи сам доживела српски шовинизам од стране професора јер нисам била „чиста “ Српкиња. То је можда био више случај за моје одељење у основној иколи и не може се генерализовати, али у средњој школи, у којој нас је било тридесетак, средина је била много здравија. (ИФ7)

ИФ5, пореклом из Новог Сада је током интервјуа говорила на мађарском, по њеном мишљењу она нема потешкоћа ни на једном од језика. Њен покојни отац је био Србин, а мајка јој је Мађарица. Испитаница има српско име. Цело школовање је прошла на мађарском, чак је и на Филозофском факултету бирала неке предмете на мађарском. Желела да се упише у језичку гимназију, што није успела, тако да се уписала у мађарско одељење новосадске гимназије општег смера. Испричала је да је њено и сестрино школовање на мађарском језику била жеља њеног оца, пошто је он био прилично свестан чињенице да ће, ако она и њена старија сестра похађају школу на српском језику, мађарски језик ослабити у већинском окружењу као што је Нови Сад. Иако ИФ5 није причала о мајчиној жељи или мишљењу о очувању мањинског идентитета у току школовања, ту одлуку у врло турбулентном времену донео је отац (Thomson 2020), док се њена мајка није питала. Следи део њеног наратива: 
Иила сам у основну и средњу школу у Новом Саду и студирала сам на Универзитету у Новом Саду, на Филозофском факултету, студирала сам Журналистику, одабрала сам и тамо мађарску групу. Да се школујемо на мађарском била је жеља мог оца, тако да смо сестра и ја ишле у мађарску школу, јер је сва родбина живела у Кањижи 12 и околини. Мислио је да ћемо, ако школу похађамо на сриском, заборавити да причамо мађарски јер смо у Новом Саду имали само неколико познаника Мађара са којима смо могли да разговарамо на мађарском. (ИФ5)

ИФ5 је говорила о својим негативним искуствима везаним за употребу мањинског језика током деведесетих, која су била углавном повезана са школским окружењем, али и изван тога, на улицама и у суседству. Следи њена прича:

То се уопштено дешавало у школи. То сам доживела кад смо мама и ја ишли негде аутобусом, некако сам осетила негативну енергију у ваздуху јер би нас људи тако на тренутак погледали. Нису проговарали. Било је један догађај, кога се сећам, у школи ... пришла ми је девојчица и рекла да она зна да ја причам српски и да треба да говорим српски јер имам српско презиме. Такође ћу рећи да смо у згради имали комшинииу, Мађарииу, син јој је био Србин, престала је да говори на мађарском деведесетих, и муж јој је био Србин. Она је једном приликом на дрво залепила папир на коме је било одитампано „Мађаре под лед!“. Мој отаи је написао чланак о томе, који је објављен и у новинама ${ }^{13}$. Моји родитељи су се веома узнемирили због тога. (ИФ5)

Деведесете су довеле до подела на националној основи, ИФ5 је испричала догађај о њиховој комшиници, која је била Мађарица, али је крила своје порекло. Комшиница је вероватно свој положај рационализовала истичући свој успех у друштвеном прихватању од стране већинског становништва (Song 2009), као и „културну значку“ (Kalmijn 1998) свог супруга у већинском окружењу, а у времену испуњеном тензијом чак је и негирала своје порекло и оставила шовинистичку поруку. На то се може гледати као на један контра пример улоге жена у рату, који је у овом случају супротан одржавању мира и моралне чистоте (Rácz 2018).

\section{Закључак}

Током ратова у Југославији деведесетих година није било оружаних сукоба у Војводини, али је национализам који се распламсао у турбулентном ратном периоду, потпириван од стране ратне пропаганде, оставио дуготрајне последице у Покрајини (Савић 2006). У раду сам анализирала последице ратова у Југославији по одређену групу миленијалаца, који су, поред тога што су одрасли током деведесетих под тензијама, потекли из мешовитих бракова. Конкретније, усредсредила сам се на сложени процес доношења одлука с којима се суочавају родитељи у мешовитом браку приликом избора наставног језика

\footnotetext{
${ }^{12}$ Кањижа (на мађарском Magyarkanizsa) је место настањено са већинским мађарским живљем на северу Војводине.

${ }^{13}$ Отац јој је био новинар. 
(мањинског или већинског), објашњеног из перспективе миленијалаца. Поред тога рад се бави и дискриминацијом и инцидентима заснованим на етничкој припадности, коју су моји испитаници доживели у периоду деведесетих година у Војводини. Своју анализу сам засновала на полуструктурираним интервјуима спроведеним са појединцима из различитих делова Војводине, како оних где већи проценат становника чине националне мањине, тако и оних места у којима је величина националних мањинских група била прилично мала у односу на укупно становништво.

Резултати показују да су испитаници који су основну школу завршили на српском језику удаљили од мањинске групе, па чак и ако су неговали мањински језик, за њих је језик постао средство за лакаше запошљавање или за даље напредовање у каријери, а не за стварање веза са мањинском групом. Они који су и основну и средњу школу завршили на мањинском језику сачували су чвршће везе са мањинском заједницом и у основи изградили и мањински идентитет. Ипак, када је реч о доминантном језику, атрибутско кодирање (види Табелу 1) показало је да је само једна испитаница изјавила да јој је мањински језик први језик (али да и српски говори на високом нивоу), једна испитаница изјавила да оба језика говори једнако добро, док за остатак испитаника српски језик је постао доминантан, са јасним нестанком или чак губитком мањинског језика (Phinney, 2003).

У анализи интервјуа дошла сам до закључка да концентрација припадника националне мањине игра двоструку улогу у одабиру језика наставе. Наиме, родитељли који живе у делу Војводине у коме живи мали број националне мањинске групе (нпр. мали број Мађара у Новом Саду) често живе даље од ограниченог броја школа које нуде наставу на мањинским језицима. Према томе, неки родитељи који живе у мешовитим браку доносе одлуку о језику школовања на основу нивоа запаженог комфора и уписују своју децу у школе са већинским језиком у близини. На вишем нивоу, те изборе обликује етнички састав општина у којима родитељи живе; ако је етничка група негде бројнија, онда тамо постоји више школа које нуде наставу на језицима националних мањина, што повећава вероватноћу да у близини постоји одговарајућа школа.

Што се тиче родне димензије, анализа интервјуа је показала да су се очеви више питали у вези са избором језика школовања током бурних деведесетих у мешовитим породицама (Thomson 2020). Било је случајева и да су очеви припадници националних мањина инсистирали на образовању своје деце на мањинском језику, као и да су очеви припадници већине познавање језика националне мањине препознали као предност коју су желели да развију код своје деце, што их је навело да одаберу наставу на језику националне мањине за своју децу. Мајке су биле мање приметне у избору језика школовања. Конкретно, једино су самохране мајке могле да утичу на ту одлуку или је саме донесу током деведесетих. То је било у супротности са традиционалним, патријархалним друштвом у коме су послове повезане са подршком дечијег образовања углавном обављале жене. Могли бисмо рећи да је такво окружење отежало очевима припадницима мањинске заједнице, чије супруге из (српске) већине нису 
говориле мањински језик, да одаберу образовање на мањинском језику за своју децу.

Резултати показују да су, без обзира на наставу на мањинском или већинском језику и род, сви испитаници током бурних деведесетих доживели непријатне ситуације и/или инциденте засноване на националној припадности. Понајвише је било вербалних инцидената у школи или током одласка у школу и повратка (нпр. у аутобусу), али су се испитанице присећале и инцидената који су се завршавали и тучом.

Напослетку, закључујем да су се миленијалци рођени у мешовитом браку суочавали са додатним етничким тензијама још од деведесетих. Наднационални југословенски идентитет (Godina 1998) нестао је током и након ратова у Југославији деведесетих година, што је учинило неопходним да испитаници бирају између идентитета већине или етничке мањине. Ако су ту одлуку свесно одбијали да донесу, они су прихватили живот у лимбу са још увек нерешеним етничким идентитетом.

Интеграција деце у једну (или другу) језичку заједницу (Мау 2012) представљало је велико питање за родитеље из мешовитих бракова у току деведесетих, али је то питање веома актуелно и данас. Наиме, родитељи настоје да њихова деца избегну језичке потешкоће у будућности (Papp 2017, Lendák-Kabók \& Lendák 2017), али и да језик(е) говоре правилно и без нагласка (Russo и група аутора 2017). Ако одаберу језик већине (тј. српски у Војводини), могу да обезбеде бољи почетни положај у друштву (Рарp 2017), док одабиром мањинског језика могу да повећају будући културни капитал своје деце (Kalmijn 1998). Одабиром наставе на језику мањине (у овом случају мађарском језику), не граде се везе само између детета, родитеља припадника националне мањине, већ и према етничкој мањинској групи и матичној држави, која је део Европске уније (ЕУ).

\section{Литература}

Aavik, K. (2015) „Intersectional disadvantage and privilege in the Estonian labor market: an analysis of work narrative of Russian - speaking women and men" Dissertation on Social Sciences. Tallinn University. DOI: 10.13140/RG.2.1.3081.0960

Bálint, I. (2012) „Van-e vajdasági-délvidéki magyar identitás?“. In Magyar Tudomány Napja Délvidéken, edited by József Szalma, 450-48. Újvidék: VMTT.

Barth, Fredrik. 1969. „Introduction“. In Fredrik Barth (Ed.) Ethnic Groups and Boundaries (pp. 1-12). Boston: Little, Brown.

Botev, N. (1994) Where East meets West: Ethnic intermarriage in the former Yugoslavia, 1962 to 1989. American Sociological Review: 461-480. DOI: 10.2307/2095944

Blau, P. M., T. C. Blum and J. E. Schwartz. (1982) Heterogeneity and intermarriage. American Sociological Review 47: 45-61. DOI: 10.2307/2095041

Bourdieu, P. (1991) Language as symbolic power. Harvard University Press. 
Bracewell, W. (1996) Women, motherhood, and contemporary Serbian nationalism. Women's Studies International Forum 19(1-2): 25-33. https://doi.org/10.1016/02775395(95)00061-5

Čudić, M. (2017) Néhány széljegyzet a vajdasági magyar identitás karakterológiáihoz. In Losoncz, M. (Ed.) Ki vagy te vajdasági magyar? (pp. 27-40). Újvidék: Forum.

Filipović J., Vučo J. and Đurić Lj. (2007) Critical review of language education policies in compulsory primary and secondary education in Serbia. Current Issues in Language Planning 8(1): 222-242.

Fox, R. G. (1996) „Gandhi and feminized nationalism in India“. In Williams B. (Ed.) Women Out of Place: The Gender of Agency and the Race of Nationality (pp. 37-49). New York: Routledge.

Godina, V. V. (1998) The outbreak of nationalism on former Yugoslav territory: a historical perspective on the problem of supranational identity. Nations and Nationalism 4(3): 409-422. https://doi.org/10.1111/j.1354-5078.1998.00409.x

Gönz, L. (2004) A vajdasági magyarság kétnyelvüsége. Szabadka: Magyarságkutató Tudományos Társaság,

Hoóz, I. (2002) A nyelvi asszimiláció és a házasságkötés. Statisztikai Szemle 12: 10821096.

Ilić, V. i Cvejić, S. (1997) Nacionalizam u Vojvodini. Zrenjanin: Gradska narodna biblioteka „Žarko Zrenjanin“.

Kalmijn, M. (1998) Intermarriage and homogamy: causes, patterns, trends. Annual Review of Sociology 24: 395-421. https://doi.org/10.1146/annurev.soc.24.1.395

Kandiyoti, D. (1994) Identity and its Discontents: Women and the Nation. Millennium: Journal of International Studies 20(3): 429-443. DOI:10.1177/0305829891020003 1501

Kemp, W. (2006) „The triadic nexus: lessons learned from the status law“. In Osamu, I. (Ed.) Beyond Sovereignty: From Status Law to Transnational Citizenship (pp. 109126). Slavic Research Center, Hokkaido University.

Kiss, T. (2018) „Assimilation and Boundary Reinforcement: Ethnic Exogamy and Socialization in Ethnically Mixed Families“. In Tamás Kiss, István Gergő, Székely, Tibor Toró, Nándor Bárdi and István Horváth (Eds.) Unequal Accommodation of Minority Rights (pp. 459-500). Palgrave Macmillan, Cham. https://doi. org/10.1007/978-3-319-78893-7_12

Kyriazi, A. (2018) The education of minorities in Bulgaria and Romania: Analyzing the formation and articulation of preferences. Ethnicities 18 (3): 412-433. https://doi. org/10.1177/1468796816684147

Labov, T. and Jacobs, A.J. (1986) Intermarriage in Hawaii, 1950-1983. Journal of Marriage and the Family 48: 79-88. DOI: 10.2307/352230

Law, J. (2004) After method. London: Routledge.

Lazar, Ž. i Aćimov, D. (2017) Mešoviti brakovi u Vojvodini kao indikator interkulturne komunikacije. Godišnjak Filozofskog fakulteta u Novom Sadu 42(2), 397-410. DOI: 10.19090/gff.2017.2.397-410 
Lendák-Kabók K. and Lendák, I. (2017) „Language barrier faced by women students and teaching staff in the higher education system in Serbia“. In Filipović J. and Vučo, j. (Eds.) Minority languages in education and language learning: challenges and new perspectives (pp. 281-294). University of Belgrade, Belgrade. https://doi. org/10.18485/fid.2017.7.ch16

Losoncz, M. (2018) „Vajdaságiság és etnikai politizálás. A vajdasági magyarság regionális önazonosságánk kérdéséhez". In Losoncz M. and Rácz, K. (Eds.) A vajdasági magyarok politikai eszmetörténete és önszervezödése 1989-1999 (pp. 39-62). L'Harmattan, Budapest.

Maran, M. (2013) Rumuni u Banatu. Osobenosti identiteta. Zbornik radova Etnografskog instituta SANU - Kulturna prožimanja: antropološke perspektive 28: 229-238.

Márton, A. (2014) „Bevezető“. In Szabó, A (Ed.) Holtszezon (pp. 7-9). Magánkiadás: Újvidék.

May, S. (2012) Language and minority rights: ethnicity, nationalism, and the politics of language. Routledge.

Merton, R. K. (1972) „Intermarriage and the social structure: fact and theory“. In Milton L. B. (Ed.) The Blending American: Patterns of Intermarriage (pp. 361-774). Chicago, IL: Quadrangle Books (Originally published in Psychiatry 4:). https://doi.org/10.108 $0 / 00332747.1941 .11022354$

Mok, T. A. (1999) Asian American dating: Important factors in partner choice. Cultural Diversity and Minority Psychology 5: 103-117. https://doi.org/10.1037/10999809.5.2.103

MacQueen K. M., E. McLellan, K. Kay and B. Milstein. (2009) Codebook development for team-based qualitative analysis. CAM Journal 10(2): 31-36. https://doi.org/10.1 $177 / 1525822$ X980100020301

Nađ, I. (2006) Nekoliko obeležja migracije vojvođanske elite. Zbornik Matice Srpske za društvene nauke 121: 445-456.

Öllös, L. (2012) Ki a magyar? Új Szó Szalon.

Örkény, A. (2005) National identity: old and new challenges. International Journal of Sociology 35(4): 28-48. https://doi.org/10.2753/ijs0020-7659350402

Osanami S., N. Irastorza and M. Song. (2016) Toward building a conceptual framework on intermarriage. Ethnicities 16(4): 497-520.https://doi.org/10.1177/1468796816638402

Özateşler-Ülkücan, G. (2019) Creating a 'we' between categories: social categories and Alevi-Sunni intermarriages. Identities: 1-19. https://doi.org/10.1080/107028 9x.2019.1627069

Pagnini D. L. and P. Morgan. (1990) Intermarriage and Social Distance among U.S. Immigrants at the Turn of the Century. American Journal of Sociology 96(2): 405-32. https://doi.org/10.1086/229534

Papp, A. Z. (2014) Hidden Ethnic Inequalities. A possible global educational exploration using PISA. Ethnicity 10: 4-40.

Papp, A. Z. (2017) „Az ifjúságkutatás aktuális kérdései nemzetközi színetereken“. In Attila Z. Papp (Ed.) Változó kisebbség: Kárpát-medencei magyar fiatalok A GeneZYs 2015 kutatás eredményei (pp. 13-28). Mathias Corvinus Collegium-Tihanyi AlapítványMTA Társadalomtudományi Kutatóközpont Kisebbségkutató Intézet. 
Phinney, J. S. (2003) „Ethnic Identity and Acculturation“. In Kevin M. Chun, Pamela Balls Organista and Gerardo Marín (Eds.) Acculturation: Advances in theory, measurement, and applied research (pp. 63-82). American Psychological Association.

Preece, S. (2008) Multilingual gendered identities: Female undergraduate students in London talk about heritage languages. Journal of Language, Identity, and Education 7(1): 41-60. https://doi.org/10.1080/15348450701804706

Rácz, K. (2018) Žene u kriznom štabu: slučaj Duhovne republike Zicer. Genero (22): 21-42. https://doi.org/10.5937/genero1822021r

Rodríguez-García, D., M. Solana-Solana and M. J. Lubbers. (2016) Preference and prejudice: Does intermarriage erode negative ethno-racial attitudes between groups in Spain?. Ethnicities 16(4): 521-546.

Russo M., G. Islam and B. Koyuncu. (2017) Non-native accents and stigma: how selffulfilling prophesies can affect career outcomes. Human Resource Management Review 27(3): 507-520. doi: 10.1016/j.hrmr.2016.12.001

Šaračević, J. (2012) „Vojvodinian Regional Identity: A Social Fact or a Modern Construct?“ Master's Thesis. Department of Nationalism Studies, CEU eTD Collection, Budapest, Hungary.

Savić, S. (2006) „Žene iz manjinskih grupa u Vojvodini- Pogled iz vizure žena iz većinskog naroda“. In Svenka Savić and Veronika Mitro (Eds.) Vajdasági magyar nők élettörténetei. Novi Sad: Futura publikacije, Ženske studije i istraživanja.

Schoen R., J. Wooldredge J. and B. Thomas. (1989) Ethnic and educational effects on marriage choice. Social Science Quarterly 70(3): 617-630.

Smits, J. (2010) Ethnic Intermarriage and Social Cohesion. What Can We Learn from Yugoslavia?. Social Indicators Research 96(3): 417-432. https://doi.org/10.1007/ s11205-009-9485-y

Sokolovska, V. (2008) Istraživanje akulturacionih procesa u Vojvodini na osnovu mešovitih brakova. Sociološki pregled 42(3): 325-341.

Song, M. (2009) Is intermarriage a good indicator of integration?. Journal of Ethnic and Migration Studies 35(2): 331-348. https://doi.org/10.1080/13691830802586476

Statistical Office of the Republic of Serbia, 2011 Census of Population, Households and Dwellings in the Republic of Serbia, Belgrade: Statistical Office of the Republic of Serbia, 2012.

Szerbhorváth Gy (2018) A délszláv háborúk emlékezete a vajdasági magyaroknál. In: Losoncz M and Rácz K (eds) A vajdasági magyarok politikai eszmetörténete és önszervezése 1989-1999 (pp. 119-142). Budapest: L’Harmattan.

Thomson, J. (2020) Gender and Nationalism. Nationalities Papers 48 (1): 3-11.

Tóth, S. J. (2019), Önigazgatás és föderalizmus: Rehák László és a jugoszláviai nemzetiségi kérdés“. In Márk Losoncz and Krisztina Rácz (Eds.) A vajdasági magyarok eszmeés politikatörténete 1945-1989 (pp. 165-180). L’Harmattan, Budapest.

Trimble, J. E. (2003) „Introduction: Social change and acculturation“. In Kevin M. Chun, Pamela Balls Organista and Gerardo Marín (Eds.) Acculturation: Advances in theory, measurement, and applied research 10 (pp. 3-13). American Psychological Association. https://doi.org/10.1037/10472-004 
Ule, M. (2012) „Reconstruction of youth in postsocialism: expectations and dilemmas“. In Carmen Leccardi, Carles Feixa, Siyka Kovacheva, Herwig Reiter and Tatjana Sekulić (Eds.) 1989 - Young people and social change after the fall of the Berlin Wall. Council of Europe. https://doi.org/10.4236/sm.2014.44027

Yuval-Davis, N. (1997) „Ethnicity, gender relations and multiculturalism“. In Pnina Werbner and Tariq Modood (Eds.) Debating cultural hybridity (pp. 193-208). London: Zed Books.

Karolina Lendák-Kabók

\title{
CHILDREN OF THE 1990S IN VOJVODINA: INTERMARRIAGE AND ETHNIC IDENTITY
}

\begin{abstract}
The 1990s Yugoslav wars avoided armed conflicts in Vojvodina, the multiethnic Northern province of Serbia,but the war still bears its consequences. Some argue that the province avoided escalation partly because of the relatively high rate of ethnic intermarriages in the Yugoslav era, which acted as bonds and bridges between the Serbs and ethnic minorities. The 1990s state-funded (Serbian) nationalist propaganda did have detrimental effects on Vojvodinian ethnic minorities which are facing high emigration rates since the 1990s. Ethnic minority millennials might be the group most adversely affected by the 1990s wars, facing open nationalism, alienation, and sidelining. One milestone event in the lives of intermarriage-born millennials was the choice of language instruction (majority or minority) when enrolling in elementary school and secondary school as well. The research aimed to investigate the education element of the many-faceted framework shaping the decisions of parents and the effects those decisions had on millennials and their identity construction. The analysis was based on semi-structured interviews conducted with millennials born into (Serbian Hungarian) intermarriages and/or exhibiting high levels of acculturation. The findings show that the respondents who enrolled in elementary school in Serbian departed from the ethnic minority group, and even if they cultivated the ethnic minority language, it became a tool for further career advancement, not a bond with their minority group. Interviewees who enrolled in elementary school in a minority language preserved a stronger bond with the ethnic minority group and essentially built an ethnic minority identity. Both groups, regardless of the language of instructions, faced nationalismfuelled incidents during their schooling, which inevitably made them more insecure and vulnerable.
\end{abstract}

Keywords: intermarriages, education, language, ethnicity, identity, 1990s, millennials, Vojvodina 